\title{
Calcium and calmodulin inhibit phosphorylation of a novel auditory nerve protein
}

\author{
Donald E. Coling, Rajiv M. Naik, Jochen Schacht * \\ Kresge Hearing Research Institute, Unicersity of Michigan, 1301 East Ann Street, Ann Arbor, MI 48109-0506, USA
}

(Received 9 June 1993; Revision received 26 Augustus 1993; Accepted 8 September 1993)

\begin{abstract}
The growing use of cochlcar prosthetic devices and demonstrations of direct ototoxic insult to spiral ganglion neurons make it imperative to gain an understanding of intracellular biochemical regulation in primary sensory neurons. Calcium and calmodulin regulate many aspects of neuronal cellular physiology through stimulation of protein kinase activity. We have previously demonstrated the presence of calmodulin-dependent protein kinase substrates in the guinea pig modiolus and, additionally, the presence of two proteins ( $12 \mathrm{kDa}$ and $81 \mathrm{kDa}$, designated as p12 and p81) whose phosphorylation is blocked by calcium and calmodulin (Coling and Schacht, 1991). Here, we investigate three models for this unusual regulatory mechanism. 'The effects of calcium, calmodulin and trifluoperazine on dephosphorylation of both proteins suggests that calmodulin inhibits protein kinase activity. P81 was identified by immunoprecipitation as the myristoylated alanine-rich C kinase substrate (MARCKS), a ubiquitous actin-binding protein. Two observations indicate that MARCKS may be regulated differently in acoustic nerve than in cerebral cortex. ${ }^{32} \mathrm{P}$ incorporation was significantly higher in acoustic nerve than in brain. The calmodulin-dependent block of MARCKS phosphorylation was observed only in acoustic nerve. p12 shares several characteristics with myelin basic protein (MBP). We used a double label assay with ${ }^{32} \mathrm{P}$ autoradiography and immunoblotting to show that p12 is in fact distinct from MBP. We suggest that either p12 or p12 kinase may be either specific to the peripheral auditory system or novel marker proteins for that tissue.
\end{abstract}

Key words: Acoustic nerve; Calcium; Calmodulin; Myristoylated alanine-rich C kinase substrate (MARCKS); Protein kinase; Protein phosphorylation

\section{Introduction}

The primary sensory neurons of the spiral ganglion form an integral link in the auditory pathway. Atrophy and demyelination of spiral ganglion cells and their processes can occur in response to aging, ototoxic drugs, acoustic overstimulation and certain hereditary diseases (Mustillo, 1984; Schwartz 1986; Dupont et al., 1993). Our understanding of the molecular events underlying acoustic nerve physiology and pathology was initiated by Wenthold and colleagues with their studies of changes in axonal transport of proteins in response to noise stimuli (Tytell et al., 1980; Wenthold and McGarvey, 1982a,b). More recently, Van De Water and associates have reported experiments on the influ-

\footnotetext{
* Corresponding author.
}

ence of trophic factors on the survival of isolated spiral ganglion neurons (Lefebvre et al., 1992a,b).

There is no information on intracellular mechanisms that regulate auditory nerve biochemistry. We anticipate that protein phosphorylation will play a major role in this regulation as is the case in most other tissues. In other neuronal tissue, for example, protein phosphorylation provides major effector systems for control of cellular physiology and homeostasis (for review, see Nestler and Greengard, 1984; Nairn et al., 1985; Cohen, 1989).

Phosphate incorporation into proteins by protein kinases and its removal by protein phosphatases constitutes a molecular switch which can dramatically alter the structure and hence function of protein substrates. Kinase and phosphatase activities are regulated by ligand binding to extracellular receptors and by binding of a variety of second messengers to intracellular effector enzymes. Of the latter, calcium and calmodulin-de- 
pendent protein kinase activity appears to be a particularly widely used system in the neural tissues of the cochlea (Coling and Schacht, 1991). We reported two auditory nerve proteins that exhibited a very unusual type of calcium and calmodulin-dependent regulation of protein phosphorylation. ${ }^{32} \mathrm{P}$ incorporation in the two proteins, 81 and $12 \mathrm{kDa}$ (designated here as $\mathrm{p} 81$ and p12), was almost completely blocked in the presence of calcium and calmodulin (Coling and Schacht, 1991).

Calcium and calmodulin form a second messenger complex which regulates protein phosphorylation as well as a variety of other important cellular reactions. In most reported cases, this regulation is mediated by stimulating calcium/calmodulin-dependent protein $\mathrm{ki}$ nases (reviewed in Nairn, 1985) or protein phosphatase 2B (calcineurin; Stewart et al., 1982). Another mode of action of calmodulin is suggested by recent experiments on the myristoylated alanine-rich $C$ kinase substrate (MARCKS, ' $87 \mathrm{kDa}$ '; Wu et al., 1982; Albert et al., 1984; Graff et al., 1989). Here, an inhibition of protein kinase activity appears to result from binding of the calcium/calmodulin complex at or near the closely spaced phosphorylation sites on the protein substrate (Graff et al., 1989; Tokumitsu et al., 1989). Phosphorylation of neuromodulin (GAP43, B50, p57, F1; Houbre et al., 1991) may be similarly regulated.

In this communication, we provide evidence that the calcium/calmodulin regulation of $\mathrm{p} 81$ and $\mathrm{p} 12$ is at the level of inhibition of the respective protein kinases. We identify p81 as the actin-binding protein, MARCKS. We also provide data which strongly suggests that p12 is a novel member of the small family of proteins whose phosphorylation is inhibited by calcium and calmodulin.

\section{Materials and methods}

\subsection{Tissue preparation}

The modiolus with the spiral ganglion was removed from the inner ears of pigmented guinea pigs (250-400 g) as described (Coling and Schacht, 1991). In some experiments, the nerve fiber core was dissected from the modiolus in order to eliminate surrounding bony tissue. After dissection, the tissue was washed and sonicated (Cole Parmer 4710, $2 \mathrm{~mm}$ tip) 4 times, $3 \mathrm{~s}$ each, in homogenization buffer $(10 \mathrm{mM}$ sodium 4-(2hydroxyethyl)-1-piperazineethanesulfonic acid (HEPES), pH 7.4, $10 \mathrm{mM} \mathrm{MgCl}_{2}, 0.2 \mathrm{mM}$ [ethylenebis (oxyethylenenitrilo)]tetraacetic acid (EGTA) with 200 $\mu \mathrm{M}$ phenylmethylsulfonyl fluoride, $2 \mu \mathrm{M}$ pepstatin A and $2 \mu \mathrm{M}$ leupeptin as protease inhibitors).

\subsection{Endogenous kinase assays}

Labeling was initiated by adding $7.5 \mu \mathrm{M}\left[\gamma^{-32}\right.$ P $]$ ATP (Amersham, spec. activity $1.06 \mathrm{fBq} / \mathrm{mol}$ ) to 1 to $5 \mu \mathrm{g}$ protein in homogenization buffer (Coling and Schacht, 1991). When indicated, $0.6 \mathrm{mM} \mathrm{CaCl}, 10 \mu \mathrm{M}$ calmodulin (Sigma, St. Louis, MO), $30 \mu \mathrm{M}$ trifluoperazine, 1 $\mu \mathrm{M}$ cyclic nucleotides, lipids $(100 \mu \mathrm{g} / \mathrm{ml}$ phosphatidylserine and $10 \mu \mathrm{g} / \mathrm{ml} 1,2$-diolein) or combinations of these agents were added. Incubations were terminated by the addition of 'stop' buffer (final concentrations, $62.5 \mathrm{mM}$ Tris- $\mathrm{HCl}, \mathrm{pH} 6.8,2 \%$ SDS, $10 \%$ glycerol, $5 \%$ 2-mercaptoethanol, $0.003 \%$ bromophenol blue) and boiling for $5 \mathrm{~min}$.

\subsection{Chase assays}

Homogenates with 1 to $5 \mu \mathrm{g}$ protein in $25 \mu \mathrm{l}$ of homogenization buffer were preincubated without radioactivity for 10 to $45 \mathrm{~min}$ at room temperature and then labeled for $30 \mathrm{~s}$ with $10.5 \mu \mathrm{M}\left[\gamma_{-}{ }^{32}\right.$ P]ATP (spec. activity $1.5 \mathrm{fBq} / \mathrm{mol}$ ). The preincubation period assured a reproducible incorporation of radioactivity in the brief labeling period presumably by establishing a steady-state of dephosphorylated substrates. The 'chase' was initiated by the addition of unlabeled ATP (final concentration $7.5 \mathrm{mM}$ ) plus or minus $10 \mathrm{mM}$ $\mathrm{CaCl}_{2}, 10 \mu \mathrm{M}$ calmodulin, or $100 \mu \mathrm{M}$ trifluoperazine. The incubation was terminated as described above.

\subsection{Electrophoresis and ${ }^{32} P$ detection}

Proteins were separated by SDS-polyacrylamide gel electrophoresis (SDS-PAGE, Laemmli, 1970) on 3 to $20 \%$ acrylamide gradient gels and phosphoproteins visualized by autoradiography. Molecular weight was estimated from protein standards by second order polynomial regression. Incorporation of ${ }^{32} \mathbf{P}$ was quantitated by liquid scintillation counting of bands cut from dried gels. Changes in phosphorylation are reported as percent of control \pm standard error. Control and experimental samples differed only by the addition of the second messenger or inhibitor. Control and experimental values were evaluated by one-tailed paired $t$-tests. A level of $P<0.05$ was chosen to indicate a significant difference.

\subsection{Protein determination}

Cold $5 \%$ trichloroacetic acid in acetone $\left(-20^{\circ} \mathrm{C}, 0.5\right.$ $\mathrm{ml}$ ) was added to $20 \mu \mathrm{l}$ of homogenate. After 10 to 30 $\min$ at $4^{\circ}$, the suspension was centrifuged $(5 \mathrm{~min}$ at $14,000 \times g)$ and the supernate aspirated. The remaining pellet was resuspended by sonication in $100 \mu \mathrm{l}$ of $1 \%$ SDS. Insoluble residue was cleared by centrifugation ( $5 \mathrm{~min}$ at $14,000 \times \mathrm{g}$ ), and the final supernate 
assayed for total protein using a bicinchoninic acid protein assay (Pierce, Rockford, IL; Smith et al., 1985).

\subsection{Immunoprecipitation}

Auditory nerve tissue (modiolus with nerve fiber core, $10 \mu \mathrm{g}$ ) or temporal cortex (20 $\mu \mathrm{g})$ were labeled as described for endogenous kinase assays and reactions were terminated by boiling in $0.5 \%$ SDS for $5 \mathrm{~min}$. Immunoprecipitation was carried out according to Nestler and Greengard (1980). Staphylococcus aureus cells (Boehringer-Mannheim Biochemicals, Indianapolis IN) were used to precipitate immune complexes formed by overnight incubation of precleared homogenate fractions with $10 \mu 1$ of either normal rabbit or rabbit anti-rat brain MARCKS serum (gift from Drs. Angus Nairn, Katherine Albert, James K.-T. Wang and Paul Greengard)

\subsection{Phosphoamino acid analysis}

The modiolus and acoustic nerve core from two cochleae were labeled with $\left[\gamma-{ }^{32} \mathrm{P}\right] \mathrm{ATP}$ in low calcium (EGTA) as described above for endogenous kinase labeling. To ensure sufficient ${ }^{32} \mathrm{P}$ incorporation for subsequent steps, specific radioactivity was increased by a factor of 10 for these experiments. p12 was gel purified by preparative electrophoresis on a $5-18 \%$ gradient slab gel. The p12 band was identified on the unstained dried gel by alignment with the corresponding autoradiograph and cut from the gel. p12 was extracted by incubation in $50 \mathrm{ml}$ ammonium carbonate ( $0.05 \mathrm{M}$ ammonium bicarbonate, $0.05 \mathrm{M}$ ammonium hydroxide) for $24 \mathrm{~h}$ at $37^{\circ} \mathrm{C}$ and concentrated by lyophilization, resuspension in $98 \%$ formic acid and repeated lyophilization. Hydrolysis was carried out at $120^{\circ} \mathrm{C}$ in $6 \mathrm{~N} \mathrm{HCl}$ for either $90 \mathrm{~min}$ under house vacuum or an additional $4 \mathrm{~h}$ under high vacuum $(2 \mu \mathrm{m}$ $\mathrm{Hg}$ ). Hydrolysates were lyophilized and amino acids were separated in two dimensions; first by electrophoresis and second by thin layer chromatography as described by Stratford et al. (1984). For improved resolution of phosphotyrosine and phosphothreonine, the chromatographic separation was repeated on the same plate. Phosphoamino acid standards (Sigma Chemical Co., St. Louis) were stained by spraying the plates with $0.1 \%$ ninhydrin in acetone. ${ }^{32} \mathrm{P}$ amino acids were detected by autoradiography.

\subsection{Double label, ${ }^{32} \mathrm{P} /$ immunoblotting}

Tissue homogenates were labeled with $\left[\gamma_{-}{ }^{32} \mathrm{P}\right.$ ATP $]$ as described for endogenous kinase assays. Biotinylated protein standards were purchased from BioRad (Richmond, CA). Control experiments confirmed that these standard proteins comigrated with unmodified standards (Sigma, St. Louis) used in previous molecular weight assignments. Proteins separated by SDS-PAGE were transferred to polyvinylidene difluoride (PVDF, Immobilon-P, Millipore, Bedford, MA) on a semi-dry transfer apparatus (Hoefer TE-77, San Francisco, CA) for $1 \mathrm{~h}$ at $0.8 \mathrm{~mA} / \mathrm{cm}^{2}$ using the buffer system described by Towbin et al. (1979). In control experiments a sheet of PVDF was placed on the cathode side of the gel during transfer and two sheets of PVDF were placed on the side of the anode to check for the migration of basic proteins toward the cathode and for the migration of small proteins through the substrate contacting the gel.

All immunoblotting operations were conducted at room temperature. PVDF blots were blocked in TBST [10 mM Tris- $\mathrm{HCl}, \mathrm{pH} 7.6,137 \mathrm{mM} \mathrm{NaCl}, 0.1 \%$ polyoxyethylene sorbitan monolaurate (Tween 20)] plus $5 \%$ nonfat dry milk for $1 \mathrm{~h}$. Blots were incubated $30 \mathrm{~min}$ in a rabbit IgG prepared against human MBP (Accurate Chemical and Scientific Corporation, Westbury, NY, AXL746) diluted 1:500 in TBST. Primary antibody was washed with two brief changes $25 \mathrm{ml}$ TBST, a 15 min wash and two $5 \mathrm{~min}$ washes of the same. The secondary antibody incubation was for $30 \mathrm{~min}$ in a $1: 1000$ dilution (TBST) of biotinylated goat anti rabbit IgG (Vector Laboratories BA-1000, Burlingame, CA). Secondary antibody was washed as described for primary. During this wash the avidin/HRP (horse radish peroxidase) complex was preincubated as per manufacturers instructions (Vector Laboratories PK-4000) with the exception that the dilution was increased to $10 \mu \mathrm{l}$ avidin (reagent $\mathrm{A}$ ) : $10 \mu \mathrm{l}$ biotinylated HRP : $3 \mathrm{ml}$ TBST. Incubation time in this solution was $30 \mathrm{~min}$. Excess avidin/HRP was washed with TBST plus $0.1 \%$ nonidet $\mathrm{P}-40$ to reduce nonspecific avidin binding ( $T$. Nair, personal communication). Wash times were as described above with an additional 5 min wash in TBST plus $0.1 \%$ nonidet $\mathrm{P}-40$ and a final $5 \mathrm{~min}$ wash in TBST. HRP binding was detected by 15,30 , and $60 \mathrm{~s}$ exposures to $\mathrm{X}$-ray film following a $1 \mathrm{~min}$ incubation in a chemiluminescent HRP substrate (Amersham, Arlington Heights, II.).

To ensure that ${ }^{32} \mathrm{P}$ was not interfering with detection of chemiluminescent bands, prior to immunoblotting, blots were briefly wetted with methanol, air dried and used to expose X-ray film (Kodak XAR-5, Rochester, NY) for $4 \mathrm{~min}$ at room temperature. This short autoradiographic exposure was four times longer than the longest subsequent chemiluminescent exposure. This control always resulted in clear film.

After chemiluminescent detcction, HRP activity was abolished by washing blots briefly in TBST followed by a 10 min incubation in $1 \mathrm{ml} 30 \%$ hydrogen peroxide: 2 ml TBST. To confirm the loss of HRP activity and chemiluminescent substrate, blots were then exposed to X-ray film for four min. This control always resulted 
in clear film.

For detection of radiolabeled proteins, blots were bricfly wetted in methanol, air dried and exposed to $\mathrm{X}$-ray film for autoradiography for $16 \mathrm{~h}$ at $-70^{\circ} \mathrm{C}$ sandwiched between two intensifying screens (DuPont Cronex Lightning Plus, Wilmington, DE).

The following landmarks were used for a careful alignment of immunoblot and autoradiographic images. For the longer chemiluminescent exposures the edge of the PVDF substrate was clearly visible as a crisp line. To establish landmarks for aligning autoradiographs, blots were firmly taped to the $X$-ray film and a dissection pin was used to pierce the blot and the film at three corners. After exposing and developing the film, the pin holes in the blot and film were realigned on a light box and the edges of the blot were carefully etched on the film. This etched perimeter superimposed precisely with the outline of the edges of the blot on chemiluminescent images.

To further check against cross contamination, autoradiographs were compared to chemiluminescent films. The most intense autoradiographic band (29 $\mathrm{kDa}$ ) was never detected as a chemiluminescent band. Conversely, the most intense chemiluminescent bands (the biotinylated molecular weight standards) were never detected on the autoradiograph. These internal controls confirmed that autoradiographic protein bands were a result of only the ${ }^{32} \mathrm{P}$ label and that chemiluminescent bands were a result of only antibody binding.

This procedure has proven to be superior to double labeling protocols which involve waiting for the ${ }^{32} \mathrm{P}$ label to decay before proceeding with immunoblotting steps for two reasons. First, it eliminates weeks to months of waiting for a result and, second, it eliminates the risk of epitope denaturation during the waiting period.

\subsection{Animal use and care}

The care and use of the animals for this project were approved by the University Committee on Use

Table 1

p81 and p12 phosphorylation in response to second messengers

\begin{tabular}{lllll}
\hline Addition & \multicolumn{4}{l}{$\begin{array}{l}\text { Phosphate incorporation } \\
\text { (\% of control) }\end{array}$} \\
\cline { 2 - 5 } & $\mathrm{p} 81$ & $\mathrm{n}$ & $\mathrm{p} 12$ & $\mathrm{n}$ \\
\hline CaM & $* 68.6 \pm 4.4$ & 5 & $* 67.2 \pm 10.4$ & 5 \\
cGMP & $106.4 \pm 8.2$ & 7 & $107.5 \pm 8.6$ & 6 \\
cAMP & $109.4 \pm 5.4$ & 7 & $113.3 \pm 7.0$ & 7 \\
lipids & $113.5 \pm 9.6$ & 6 & $137.2 \pm 28.2$ & 6
\end{tabular}

Tissue homogenates from the auditory nerve were assayed for endogenous kinase activity as described in Materials and methods. Phosphate incorporation relative to controls $\left(0.6 \mathrm{mM} \mathrm{CaCl} \mathrm{m}_{2}\right.$ only) are given as means \pm s.e.m. for additions of $0.6 \mathrm{mM} \mathrm{CaCl} 2$ plus 10 $\mu \mathrm{M}$ calmodulin (CaM), $1 \mu \mathrm{M}$ cGMP, $1 \mu \mathrm{M}$ cAMP, or lipids (100 $\mu \mathrm{g} / \mathrm{ml}$ phosphatidylserine, $10 \mu \mathrm{g} / \mathrm{ml}$ diolein). Asterisk indicates significant difference from control, $P<0.02$.

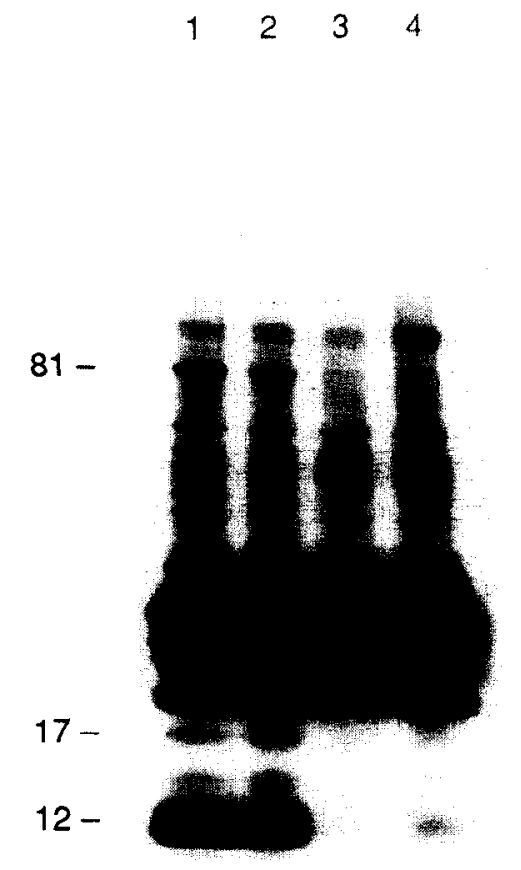

Fig. 1. A calcium/calmodulin-dependent block in phosphorylation of p81 and p12 is antagonized by trifluoperazine in homogenates from the distal portion of the auditory nerve and spiral ganglion. Tissue was prepared as described in text for endogenous kinase assays. Labeling was conducted in the presence of $0.2 \mathrm{mM}$ EGTA for each condition with the following additions: lane 1, homogenization buffer only; lane $2,0.6 \mathrm{mM} \mathrm{CaCl}{ }_{2}$; lane $3,0.6 \mathrm{mM} \mathrm{CaCl}$ plus $10 \mu \mathrm{M}$ bovine calmodulin; lane 4 calcium and calmodulin as lane 3 plus 30 $\mu \mathrm{M}$ trifluoperazine. Autoradiograms are shown after separation of proteins by SDS-PAGE.

and Care of Animals, the University of Michigan for NIH program project grant DC-00078 Perception and Processing of Complex Biological Signals.

\section{Results}

\subsection{Calcium / calmodulin-dependent phosphorylation}

In the presence of low calcium ( $0.2 \mathrm{mM}$ EGTA), the phosphoproteins most prominently labeled by $\left[\gamma^{-32} \mathrm{P}\right]$ ATP had molecular weights of $29,28,12,17$ and 81 $\mathrm{kDa}$, in descending order of ${ }^{32} \mathrm{P}$ incorporation. Addition of calcium and calmodulin did not change the phosphorylation of the 29 and $28 \mathrm{kDa}$ proteins.

${ }^{32} \mathrm{P}$ incorporation into $\mathrm{p} 81$ and $\mathrm{p} 12$, however, was significantly reduced ( 31.4 and $32.8 \%$, respectively, $P$ $<0.02$, Table 1) in response to added calcium and calmodulin (Fig. 1, lanes 2 and 3 compared to lanes 1). In contrast, under the same conditions, addition of other second messengers (cAMP, cGMP and lipids) produced no significant changes in phosphorylation in these two proteins (Table 1).

The calmodulin-dependent reduction of ${ }^{32} \mathrm{P}$ incorporation into p 81 and p 12 was partially blocked by the 
concurrent addition of the calmodulin antagonist trifluoperazine as evidenced by an increase in intensity of the $\mathrm{p} 81$ and $\mathrm{p} 12$ bands on autoradiographs (Fig. 1, lane 4 compared to lane 3 ). The reduction and its antagonism by trifluoperazine was also observed in preparations of the nerve fiber core removed from the bony modiolus (data not shown).

In four of six experiments, the response to added calcium, calmodulin and trifluoperazine of a p17 phosphoprotein mimicked that of $\mathrm{p} 81$ and $\mathrm{p} 12$, suggesting all three may be regulated by a similar mechanism. However, labeling of p17 was inconsistent and could not always be detected. Thus, further statistical analysis of the regulation of this protein by calcium and calmodulin must await determination of appropriate reaction conditions.

\subsection{Calcium / calmodulin-independent dephosphoryla- tion}

Calcium and calmodulin could be exerting their effects by stimulating a phosphatase or a protease. To test these possibilities, dephosphorylation was measured in a chase assay. Here, proteins are labeled with radioactive ATP for a brief period; then labeling is essentially halted by addition of excess nonradioactive ATP. The ensuing loss of ${ }^{32} \mathrm{P}$ label in proteins is an indication of either proteolysis or dephosphorylation. To establish the optimal time interval for determining

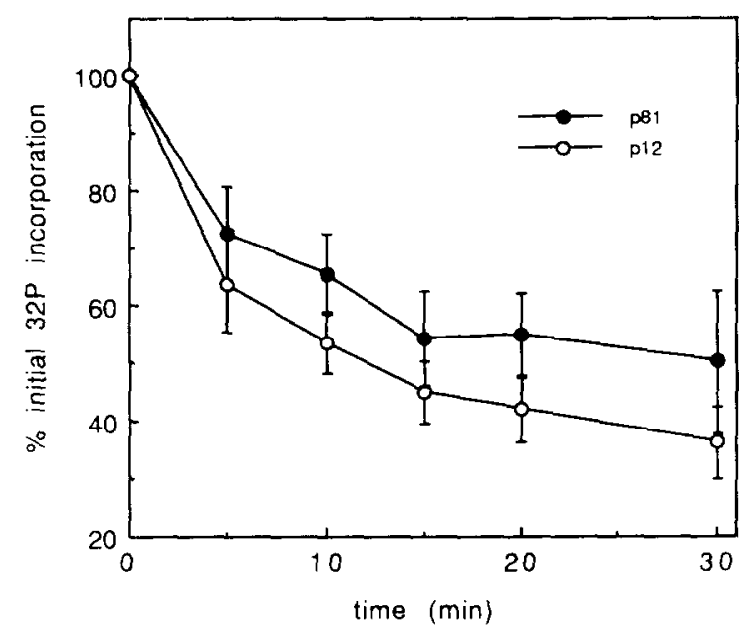

Fig. 2. Time courses for dephosphorylation of $\mathrm{p} 81$ and $\mathrm{p} 12$. Aliquots of auditory nerve homogenate were labeled in low calcium conditions. After $30 \mathrm{~s}$ the 'chase' was initiated by addition of unlabeled ATP, $\mathrm{CaCl}_{2}$ and bovine calmodulin as described in text. For the 0 time point, 'stop buffer' was included in the additions followed immediately by boiling. For the other time points, dephosphorylation was allowed to proceed in the presence of unlabeled ATP, calcium and calmodulin before the addition of 'stop buffer' and boiling. ${ }^{32} \mathrm{P}$ incorporation was measured in bands cut from dried gels. Dephosphorylation of p 81 and $p 12$ is plotted as the percent of radioactivity at time 0 (initiation of the 'chase'). Values are means S.E.M. $\mathbf{n}=3$.

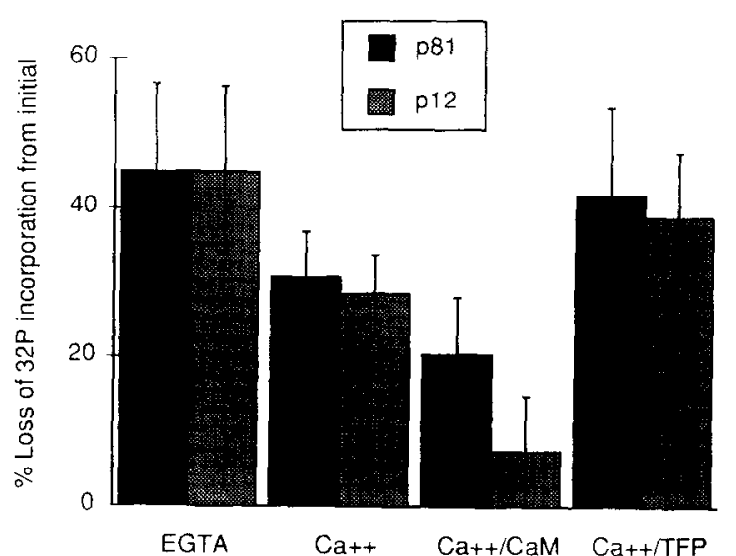

Fig. 3. Effects of calcium, calmodulin and antagonist trifluoperazine on dephosphorylation of $\mathrm{p} 81$ and $\mathrm{p} 12$. Chase assays were conducted as described in the legend for figure 2 except reactions were stopped after $5 \mathrm{~min}$. Relative rate of dephosphorylation is plotted as the percentage loss of ${ }^{32} \mathrm{P}$ at 5 min compared to a paired control sample stopped with simultaneous addition of SDS and unlabeled ATP after the $30 \mathrm{~s}$ labeling period. Additions during the chase period are given in Experimental Procedure and indicated as abscissa labels in the figure. A high\% loss indicates high phosphatase activity.

rates of dephosphorylation, we first measured the time course of loss of ${ }^{32} \mathrm{P}$ label in $\mathrm{p} 81$ and $\mathrm{pl} 2$ with calcium and calmodulin present during the chase period (Fig. 2). Potential proteolysis was additionally limited by reducing the labeling period from $15 \mathrm{~min}$ to $30 \mathrm{~s}$. Both p81 and p12 incorporated sufficient ${ }^{32} \mathrm{P}(256 \pm 26$ and $3000 \pm 208 \mathrm{cpm} / \mathrm{mg}$ total protein, respectively, $\mathrm{n}=32$ ) during the $30 \mathrm{~s}$ labeling period to allow subsequent measurement of loss of label. Following the addition of unlabeled ATP, a time-dependent reduction in ${ }^{32} \mathrm{P}$ content was observed in all auditory nerve phosphoproteins resolved by SDS-PAGE. There was no increase in ${ }^{32} \mathrm{P}$ incorporation in lower molecular weight proteins during this period indicating an absence of calcium-dependent protease activity. With calcium and calmodulin added during the chase period, the rate of loss of label of $\mathrm{p} 81$ and $\mathrm{p} 12$ was greatest during the initial 5 min (Fig. 2).

Consequently, we used five min as the optimal time interval for subsequent chase assays testing the effects of calcium and calmodulin on the rates of dephosphorylation of $\mathrm{p} 81$ and $\mathrm{p} 12$ (Fig. 3). Here, a higher \% loss of ${ }^{32} \mathrm{P}$ incorporation from initial values after a $5 \mathrm{~min}$ chase corresponds to an increased rate of dephosphorylation, ie. increased phosphatase activity.

The addition of calcium and calmodulin produced a trend toward decreasing phosphatase activity (Fig. 3 $\mathrm{Ca}^{2+}$ and $\mathrm{Ca}^{2+} /$ calmodulin vs. EGTA). For $\mathrm{p} 12$, the presence of calcium plus calmodulin resulted in significantly lower rates of dephosphorylation $(P<0.02)$. Furthermore, addition of calcium and trifluoperazine during the chase period (Fig. 3, $\mathrm{Ca}^{2+} /$ trifluoperazine) apparently reversed the calcium effect. 


\subsection{Determination of phosphoamino acids in $p 12$}

The majority of ${ }^{32} \mathrm{P}$ incorporation was detected as phosphoserine with a trace amount of phosphothreonine. Relative ratios of phosphoserine : phosphothreonine: inorganic phosphate (a hydrolysis product of phosphoamino acids) determined by densitometry were $100: 3: 21$ and $100: 2: 170$ for 1.5 and $5.5 \mathrm{~h}$ of hydrolysis, respectively. No phosphotyrosine was detected after extensive autoradiographic exposure $(10 \mathrm{~d}$, double intensifying screens, $-70^{\circ}$ ). With these conditions, background levels on the autoradiographs in the region of the phosphotyrosine standard were one order of magnitude below the phosphothreonine signal for a spot of equal area. Several additional spots containing ${ }^{32} \mathrm{P}$ migrated only in the second dimension (chromatography) but not in the first (electrophoresis). ${ }^{32} \mathrm{P}$ content of these spots was reduced by increased hydrolysis time consistent with the expected behavior of incompletely hydrolyzed peptide fragments.

\subsection{Identification of $p 81$}

Antiserum against MARCKS (Albert et al., 1984) recognized $81 \mathrm{kDa}$ phosphoproteins in both spiral gan-

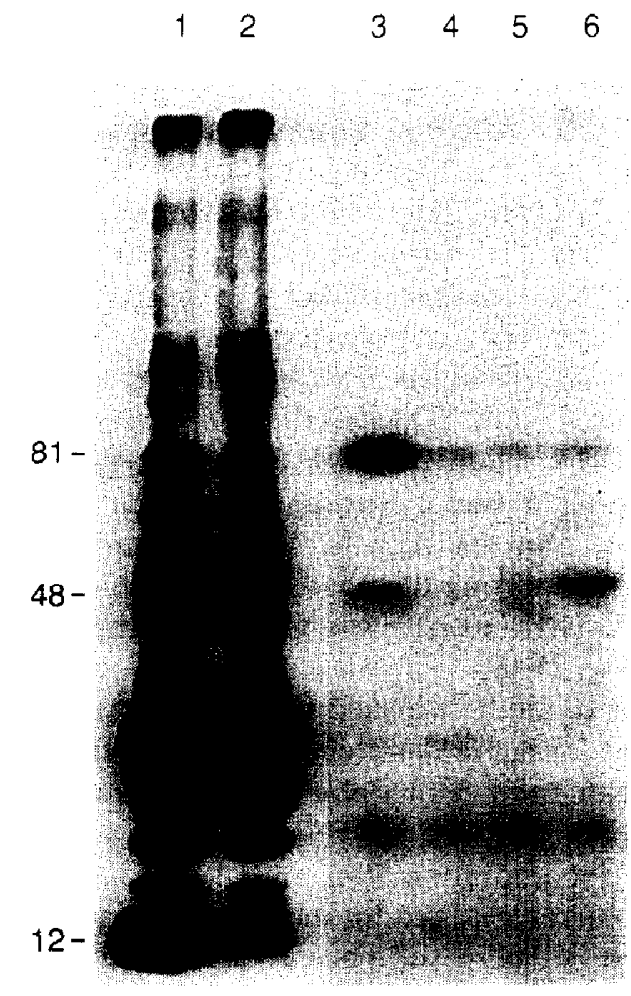

Fig. 4. $p 81$ is immunoprecipitated by antiserum prepared against MARCKS. Homogenates from auditory nerve (lanes 1-4) and brain (lanes 5 and 6) were tabeled in the absence (odd numbered lanes) or presence (even numbered lanes) of calcium and bovine calmodulin as described in text. Phosphoproteins are visualized as bands on an autoradiograms. $\mathbf{p} 81$ is identified from whole tissue samples (lanes 1 and 2) by its characteristic calcium/calmodulin-dependent reduction in ${ }^{32} \mathrm{P}$ incorporation. Antiserum against MARCKS precipitated an $81 \mathrm{kDa}$ protein from both tissues (lanes 3-6).
1 a 2 a

1b $2 b$

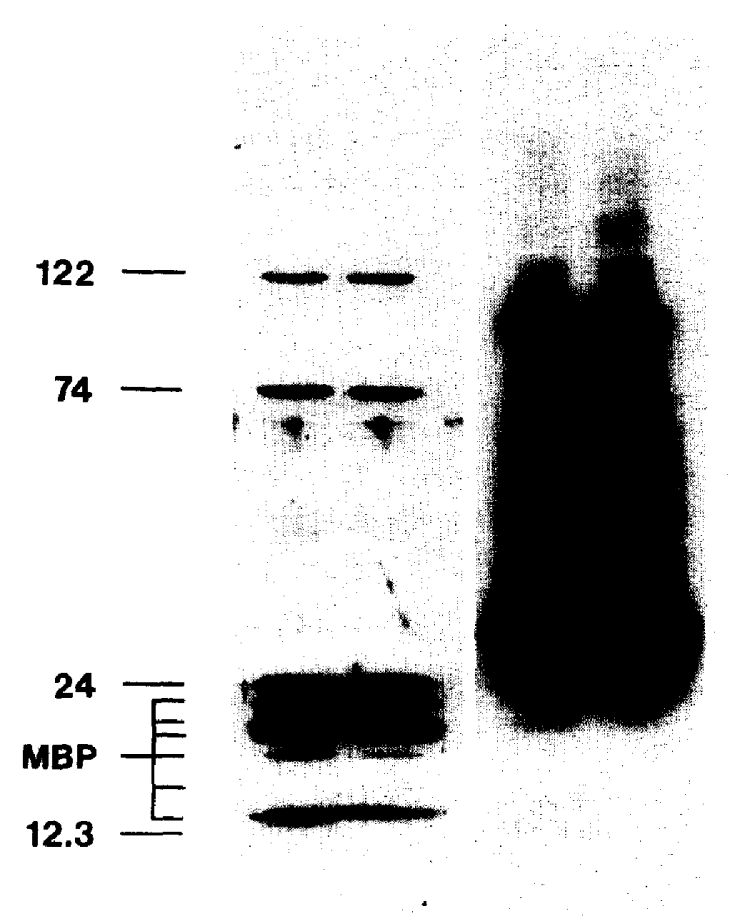

Fig. 5. p12 is distinct from myelin basic protein. Modiolar homogenates were prepared as described in Methods. Proteins from the same blot are labeled by both chemiluminescence with antibodies against myelin basic protein (lanes $1 \mathrm{a}$ and $2 \mathrm{a}$ ) and by ${ }^{32} \mathrm{P}$ autoradiography (lanes $1 b$ and $2 b$ ). The sample for lanes $1 a$ and $b$ was labeled in low calcium ( $0.2 \mathrm{mM}$ EGTA) while that for lanes $2 \mathrm{a}$ and $\mathrm{b}$ was labeled in the presence of added calcium $\left(0.6 \mathrm{mM} \mathrm{CaCl}_{2}\right)$ and calmodulin $(10 \mu \mathrm{M})$. p12 is indicated by the $12.3 \mathrm{kDa}$ band. Myelin basic protein (MBP) isoforms are indicated by the bracket ( 12.5 to 22 $\mathrm{kDa})$. Other proteins indicated are visualized $(24,74$ and $122 \mathrm{kDa})$ as a result of nonspecific binding of biotinylated secondary antibody and avidin.

glia and brain with a high degree of specificity (Fig. 4, lanes 3-6). The immunoprecipitated proteins comigrated with p81 from untreated auditory nerve tissue. The latter was identified by its characteristic calcium/ calmodulin-dependent reduction in ${ }^{32} \mathrm{P}$ incorporation (Fig. 4, lanes 1 and 2). The $81 \mathrm{kDa}$ protein precipitated from auditory nerve also exhibited this reduction (Fig. 4 , lanes 3 and 4) while that from brain did not (Fig. 4, lanes 5 and 6 ).

A $48 \mathrm{kDa}$ phosphoprotein was also precipitated by the MARCKS antiserum from auditory nerve and brain. These bands appeared only in the immunoprecipitate from auditory nerve labeled in low calcium (Fig. 4, lane 3 ) and in that from brain labeled in high calcium and calmodulin (Fig. 4, lane 6). They are further characterized by a concave downward shape for the former and a concave upward shape for the latter. The significance of these observations is undetermined but may indicate limited proteolysis or the presence of MARCKS homologues or MARCKS-binding phosphoprotein(s). Other 
minor phosphoproteins observed in the immunoprecipitate had mobilities corresponding to those that nonspecifically bound to $S$. aureus cells in the preclearing step. Under the same conditions, normal rabbit serum failed to precipitate phosphoproteins from either tissue.

\subsection{Comparison of p12 to $M B P$}

In order to ascertain whether p12 is distinct from the $14 \mathrm{kDa}$ MBP a double labeling procedure was employed. In these experiments ${ }^{32} \mathrm{P}$-labeled modiolar proteins were transferred to a solid substrate which was probed with polyclonal antibodies against MBP and processed for autoradiography as described in Methods. p12 was clearly resolved from any proteins recognized by antibodies against MBP. p12 (12.3 kDa) was clearly identified in the autoradiograph by its diminished ${ }^{32} \mathrm{P}$ incorporation in the presence of calcium and calmodulin (Fig. 5, lanes $1 \mathrm{~b}$ vs. 2b, respectively). Protein bands at 22, 20,18,17, 14, and $12.5 \mathrm{kDa}$ were specifically recognized by antibodies against MBP (Fig. 5, lanes 1a and 2a, MBP). The first four of these, 22-14 kDa correspond to the known molecular weights of MBP (Martenson, 1992). A $12.5 \mathrm{kDa}$ MBP has not been described for mammalian nervous tissue. Control experiments suggested that the $12.5 \mathrm{kDa}$ protein band is a proteolytic fragment that results from hydrolysis of the $14 \mathrm{kDa}$ MBP. When tissue was incubated at a lower temperature $\left(0^{\circ} \mathrm{C}\right)$ over a shorter period of time (10 $\mathrm{min}$ ) before analysis by SDS-PAGE and immunoblotting the $14 \mathrm{kDa}$ chemiluminescent band was more intense than that shown in Fig. 5 and the 12.5 $\mathrm{kDa}$ band was not detectable. Additional nonspecific bands in Fig. 5 at 122, 74 and $24 \mathrm{kDa}$ were also detected in controls in the absence of primary antibody.

\subsection{Tissue distribution of $p 12$}

We have surveyed a number of tissues for the presence of p12 [heart, brain, liver, kidney, cochlear sensory epithelium and lateral wall (Coling and Schacht, 1991); sciatic and optic nerves, vestibular ganglion and nerve (this study)]. Cranial nerve VIII is the only tissue of those tested where we have detected a $12 \mathrm{kDa}$ phosphoprotein whose ${ }^{32} \mathrm{P}$ incorporation is blocked by calcium and calmodulin.

\section{Discussion}

The only mechanism that can account for the inhibition of phosphorylation of $\mathrm{p} 12$ and $\mathrm{p} 81$ in auditory nerve (Fig. 1) is a calmodulin-dependent block of protein kinase activity. This type of regulation has been demonstrated for the phosphorylation of MARCKS by protein kinase C in other systems (Graff et al., 1989). This mechanism has been suggested for only four other proteins: neuromodulin (Houbre et al., 1991), neurogranin (Baudier et al., 1991), MBP (Grand and Perry, 1980 ) and a 200 amino acid protein whose cDNA contains a domain highly homologous with the phosphorylation sites and calmodulin-binding domain of MARCKS (Umekage and Kato, 1991).

Alternative models for the calmodulin-dependent decrease of phosphorylation of $p 12$ and $p 81$ involve stimulation of phosphatase or protease activity by calmodulin. These models are ruled out by the experimental evidence. Either mechanism predicts calcium and calmodulin will stimulate the rate of loss of ${ }^{32} \mathrm{P}$ during chase experiments. In fact, our results show the opposite. Dephosphorylation of p12 was significantly inhibited by calcium and calmodulin (Fig. 3). Dephosphorylation of $\mathrm{p} 81$ followed the same trend. These results indicate that the lower rate of phosphorylation in the presence of calmodulin (Fig. 1) cannot be due to the stimulation of either a protein phosphatase (calcineurin, protein phosphatase $2 \mathrm{~B}$ ) or a protease.

The inhibition of dephosphorylation of $\mathrm{p} 12$ and $\mathrm{p} 81$ by calmodulin (Fig. 3) could be indirect through calmodulin-dependent activation of inhibitors of protein phosphatases 1 or $2 \mathrm{~A}$ (Cohen, 1989). Alternatively, it could be mediated by binding of calmodulin to a domain close to the phosphorylation sites of $\mathrm{p} 12$ and p81 blocking both phosphorylation and dephosphorylation. Calmodulin appears to inhibit phosphorylation of MARCKS by this mechanism (Graff et al., 1989; Tokumitsu et al., 1989).

We have identified p81 as MARCKS by immunoprecipitation. Regulation of phosphorylation and dephosphorylation of p12 mimics that of MARCKS. We suggest that $\mathrm{p} 12$, a major phosphoprotein of the auditory nerve, is a new member of the family of proteins whose phosphorylation is regulated by the same mechanism. Since we have only detected p12 in tissue from cranial nerve VIII, it seems reasonable to adopt the tentative hypothesis that either $\mathrm{p} 12$ or $\mathrm{p} 12$ kinase may be specific to the inner ear or at least an abundant marker protein for this tissue.

It is unlikely that $p 12$ is a proteolytic product of MARCKS. If this were the case, ${ }^{32} \mathrm{P}$ incorporated in p12 should increase during the chase when in fact it did not. Additionally, p12 is not recognized by polyclonal antiserum raised against MARCKS. These data are consistent with the hypothesis that $\mathrm{p} 12$ is a distinct kinase substrate and not a proteolytic fragment derived from MARCKS or from some other phosphoprotein of higher molecular weight.

Neurogranin is a neuronal protein of molecular weight close to that of $\mathrm{p} 12$. Phosphorylation of neurogranin is also calmodulin-dependent, but appears to 
have opposite calcium sensitivity as that of $\mathrm{p} 12$ (Baudier et al., 1991). Thus, identity is unlikely.

Phosphorylation of MBP, on the other hand, is similar to that of p12. MBP is also a substrate for calcium-independent kinases (Nairn et al., 1985). As in the case of $\mathrm{p} 12$, phosphorylation of MBP is blocked by calcium and calmodulin (Grand and Perry, 1980). The distal portion of the auditory nerve which constitutes the bulk of the tissue in our preparation contains abundant amounts of myelin. We have observed that both $\mathrm{p} 12$ and the calcium-independent $\mathrm{p} 12$ kinase partition in a particulate fraction (Coling and Schacht, unpublished observation) as expected for myelin proteins. Although the apparent molecular weight of p12 does not correspond to that of the many known posttranscriptional variants of MBP (Martenson, 1992; Greenfield et al., 1982), it needs to be considered that p12 may be a novel tissue-specific MBP. This, however, remains a formal possibility only. Different molecular weight MBP translation products result from alternative splicing of the primary RNA transcript. Splicing out exons 2, 5 and 6, a type of processing that has not been reported in mammals, would result in a protein with a predicted molecular weight close to that of $\mathrm{p} 12$ (Martenson, 1992). This hypothesis, however, places restrictions on the distribution of the antigenic epitopes. The fact that $\mathrm{p} 12$ is not recognized by the polyclonal anti-MBP used in this study (Fig. 5), requires that all of the antigenic epitopes recognized be restricted to exons 2,5 , and 6 . Thus, until sequence data is available, the working hypothesis that $\mathrm{p} 12$ is distinct from MBP seems more likely.

Analysis of phosphoamino acids of p12 indicates that p12 kinase is a member of the serine/threonine kinase family. The predominant phosphorylation involves modification of serine. Although the detection of phosphothreonine is intriguing owing to the relative infrequency of threonine phosphorylation (Nairn, 1985), it is possible that the threonine phosphorylation we detected was either from a nonstoichiometric phosphorylation of $\mathrm{p} 12$ or from a minor protein that comigrated with $\mathrm{p} 12$.

Clues to the function of $\mathrm{p} 12$ and $\mathrm{p} 81$ may be found by understanding their regulation. Calmodulin-dependent inhibition of protein phosphorylation is rare. Our interest in p12 and in p81 (MARCKS) is motivated not only by the possibility that $\mathrm{p} 12, \mathrm{p} 12$ kinase or $\mathrm{p} 81$ kinase may be specific to the auditory system, but also by the relatively novel nature of the inhibitory mechanism.

The function of the proteins regulated by this mechanism is not yet well established. However, the emerging role of MARCKS in remodeling of the cortical cytoskeleton is fascinating. MARCKS is an actin bundling protein that can translocate from plasma membrane to cytosol. These processes are intricately regulated by calmodulin and protein phosphorylation. Phosphorylation appears to mediate translocation from membrane to cytosol; calmodulin inhibits both phosphorylation of MARCKS and its binding to actin (Graff et al., 1989; Thelen et al., 1991; Hartwig et al., 1993). The results of the present study (Fig. 3) raise the possibility that calmodulin may also inhibit dephosphorylation. The balance of these regulatory mechanisms would provide a means of controlling interactions of the plasma membrane and the cytoskeletal lattice.

Two differences in the phosphorylation of MARCKS in auditory nerve compared to brain may provide clues for specializations specific to the inner ear. First, ${ }^{32} \mathrm{P}$-incorporation in MARCKS (per mg total protein) is much higher in the auditory nerve than in cerebral cortex under conditions of low calcium. This difference is consistent with either a higher abundance of MARCKS or a higher activity of its kinase in auditory nerve. MARCKS phosphorylation is generally associated with protein kinase C (PKC) activity (Wu et al., 1982; Hartwig et al., 1992). It has been proposed that myelin fractions may contain a specific proteolytic fragment of PKC that is catalytically active without calcium (Nairn, 1985). This possibility may also account for the failure of PKC activators (diacylglyceride and phosphatidylserine) to stimulate the phosphorylation of either p12 or p81. Second, the pronounced calmodulin-dependent inhibition of phosphorylation of MARCKS was seen in homogenates of auditory nerve but not brain. This type of inhibition of MARCKS phosphorylation has so far only been reported in subcellular fractions such as synaptosomes (Albert et al., 1984) and in reconstituted enzyme systems (Graff et al., 1989; Tokumitsu et al., 1989). The differences between auditory nerve and brain may be due to several factors, including a tissuespecific protein kinase or, conceivably, an auditoryspecific MARCKS isoform. This information coupled with future experiments on the localization of $\mathrm{p} 12$ and MARCKS in the cochlea and auditory nerve should provide some useful insights on the role of these proteins in the regulation of cellular physiology in the inner ear.

\section{Acknowledgements}

The authors wish to thank Drs. T. Ueda and C. Bovenkerk for advice and assistance with phosphoamino acid analysis and Drs. A. Nairn, K. Albert, J.K.-T. Wang and P. Greengard for sharing recent data on the MARCKS protein and for a generous gift of antiserum. We also thank S. Crann, J. Fessenden and Dr. G. Tennekoon for valuable comments on the manuscript. The work was supported by the NIH program project grant $\mathrm{DC}-00078$ and training grant $\mathrm{DC}$ 00011 . 


\section{References}

Albert, K.A.. Wu, W.C.S., Nairn, A.C., Greengard. P. (1984) Inhibition by calmodulin of calcium/phospholipid-dependent protein phosphorylation. Proc. Natl. Acad. Sci. USA 81, 3622-3625.

Albert, K.A., Walaas, S.I., Wang, J.K.-T, and Greengard, P. (1986) Widespread occurrence of " $87 \mathrm{kDa}$," a major specific substrate for protein kinase C. Proc. Natl. Acad. Sci. USA 83, 2822-2826.

Baudier, J., Deloulme, J.C.. Van Dorsselaer, A., Black, D. and Matthes, H.W.D. (1991) Puritication and characterization of a brain-specific protein kinase $\mathrm{C}$ substrate, neurogranin $(\mathrm{p} / \mathrm{7})$. J. Biol. Chem. 2ho, 229-237.

Cohen, P. (1989) The structure and regulation of protein phosphatases. Ann. Rev. Biochem. 58, 453-508.

Cohen, P. and Klee, C.B. (1988) Calmodulin, Elsevier, Amsterdam.

Coling, D.E. and Schacht, J. (1991) Protein phosphorylation in the urgarl of Curti: Differential legulation by second messengers between base and apex. Hear. Res. 57, 113-120.

Dupont, J.. Guilhatume, A. and Aran. J-M. (1993) Neuronal degeneration of primary cochlear and vestibular innervations after local injection of sisomicin in the guinea pig. Hear. Res. 68, 217-228.

Gratt. J.M. Young. T.N., Johnson, D. and Blackshear, P.J. (1989) Phosphorylation-regulated calmodulin binding to a prominent cellular suhstrate for protein kinase C.J. Biol. Chem. 264, 21818 21823 .

Grand. R.J.A. and Perry. S.V. (1980) The hinding of calmodulin to myelin basic protein and histone H2B.J. Biochem. 189, 227-240.

Hartwig, J.H., Thelan. M.. Rosen, A.. Janmey, P.A., Nairn, A.C. and Aderem, A. (1992) MARCKS is an actin filament crosslinking protein regulated by protein kinase $\mathrm{C}$ and calcium-calmodulin. Nature $356,618-622$.

Hidaka. H., Watanabe, M. and Tokumitsu, H. (1990) Seareh for the functional substrate proteins of protein kinases and their selective inhibitors. In: Nishizuka et al. (Eds.), The Biology and Medicine of Signal Transduction, Raven Press, New York. pp. $485-4 \%(0)$

Houbre, D., Duportail, G., Deloulme, I.C. and Baudier, J. (199I) The interactions of the brain-specifie calmodulin-binding protein kinase $C$ sultstrate, neuromodulin (GAP 43), with membrane phöspholipids. J. Biol. Chem, 266. 7121-7131.

Lacmoli, U.K. (1970) Cleavage of structural proteins during the assembly of the head of hacteriophage T4. Nature 227, 680-685

Lefebre, P.P., Van De Water, T.R.. Staecker, H., Weber, T., Galinovic-Schwartz. V., Moonen. G. and Ruben, R.J. (1992a) Nerve growtls fictor stimulates neurite regeneration but not survival of adult auditory neurons in vitro. Acta Utolaryngol. 112, 288-93.

Lefebvre, P.P. Weber, T., Rigo, T., Staecker, H., Moonen. G. and Van De Water, T.R. (1992h) Peripheral and central target-derived trophic factor(s) effects on auditory neurons. Hear. Res. 58 , $1 \times 5-192$.

Martenson, R.E. (1492) Myelin basic protein isoforms: Structural and cvolutionary implications of altenative exon splicing. In: R.E. Martenson (Ed,) Myelin: biology and chemistry, CRC Press. Bocd Raton. pp. 387-411
Melloni, E, and Pontremoli, S. (1989) The calpains. Trends Neurosei. $12,438-444$.

Mustillo, P. (1984) Auditory deficits in multiple sclerosis: a review Audiology 23, 145-164.

Nairn. A.C. Hemmings, H.C. and Greengard. P. (1985) Protein kinases in the brait. Ann. Rev. Biochem. 54, 931-976.

Nestler. E.J. and Greengard P. (1980) Dopsmine and depolarizing agents regulate the state of phosphorylation of protein $I$ in the mammalian superior cervical sympathetic ganglion. Proc. Natl. Acad. Sci. USA $77,7479-7483$

Nestler, E.J. and Grecngard P. (1984) Protein Phosphorylation in the Nervous System, John Wiley and Sons. New York.

Schwartz. A.M. (1986) Auditory nerve and spirai ganglion cells Morphology and organization. In: R.A. Altschuler. R.P. Bobbin and D.W. Hoffman (Eds.), Neurobiology of Hearing: The Cochlea. Raven Press, New York. pp. 271-282.

Smith P.K.. Krohn, R.I., Hermanson, G.T., Mallia. A.K., Gartner. F.H., Provenzano, M.D., Fujimoto, E.K., Goeke, N.H., Olson. B.J. and Klenk, D.C. (1985) Measurement of protein using hicinchoninic acid. Anal. Biochem. 150, 76-85

Stewart, A.A., Ingebritsen. T.S., Manalan. A., Klce. C.B. and Cohen P. (1982) Discovery of a $\mathrm{Ca} 2+$ - and calmodulin-dependent protein phosphatase: Yrobable identity with calcineurin (CaM-BP\&O) FEBS Lett. 137, 8()-84,

Stratford, C.A., Fisher, S.K. and Ucda. T. (1984) Ergopeptine-sensitive calcium-dependent protein phosphorylation systems in the hrain. J. Neurochem. 42, 842-855.

Thelen, M., Rosen, A., Nairn, A.C. and Aderem. A. (1991) Regulation by phosphorylation of reversible association of a myristoylated protein kinase $C$ substrate with the plasma membrane. Nature 351, 320-322.

Tokurnitsu. H., Mizulani, A. Namura, S. Watanabe, M., and Hidaka. H. (1989) Purification and characterization of $81 \mathrm{k}$, heat stahle calmodulin-binding protein from bovine brain. Biochem. Biophys Res. Commun. 16,3,581-588.

Tytell, M. Gulley, R.L.. Wenthold, R.J.. and Lasek, R.J. (1980) Fast axomal transport in auditory neurons of the guined pig: a rapidly Iurned-over glycoprotein. Proc. Natl. Acad. Sci. USA 77, 30423046.

Umekage. T. and Kato, K. (1891) A mouse brain cDNA encodes a novel protein with the protein kinase $C$ phosphorylation site domain comnon to MARCKS. FEBS Lett. 286. 147-151,

Wenthold. R.J. and McGarvey. M.L. (1982a) Changes in rapidly transported proteins in the auditory nerve after hair cell loss. Brain Res. 253, 263269.

Weathold. R.J. and McGarvey. M.L. (1982b) Difierent polypeptides are rapidly transported in auditory and optic neuron. J. Neurochem. 39, 27-35.

Wu. W.C. Walads. S.I., Nairn, A.C. and Greengard, P. (1982) Calcium/phospholipid regulates phosphorylation of at $M_{r}$ " $87 \mathrm{k}$ " substrate protein in brain synaptosomes. Proc. Natl. Acad. Sci. USA $79.5249-5253$. 